\title{
Possibility of Aluminium/Magnesium Exchange in Composite Rocket Propellants
}

\author{
Vesna Rodić ${ }^{1)}$ \\ Marica Bogosavljević ${ }^{1)}$ \\ Saša Brzicín ${ }^{1)}$ \\ Bojana Fidanovski ${ }^{1)}$
}

\begin{abstract}
Composite solid propellants based on ammonium perchlorate/hydroxyterminated polybutadiene/isophorone dyisocyanate including two metal components: aluminium and magnesium with different contents have been represented in this paper. The mass of metal powder has increased in relation to oxidant, with constant bimodal fraction ratio and total solid phase. Parameters of burning rate laws, apparent viscosity, uniaxial mechanical characteristic, density and energetic values have been determined and compared in accordance to the propellants of the smoke reduction research.
\end{abstract}

Key words: composite rocket propellant, ammonium perchlorate, hydroxyterminated polybutidiene, aluminium, magnesium, ballistic characteristics, mechanical characteristics, comparison results.

\section{Introduction}

$\mathrm{M}$ OST of the current operational solid propellants make use of ammonium perchlorate as an oxidizer. The main disadvantage of that inorganic salt is its chlorinated exhaust products that are detrimental to the environment and produce a distinct smoke signature behind missiles that can easily be detected. Except that, guiding the rocket missile becomes more difficult.

A huge amount of released chlorinated gas products contaminates the atmosphere and contributes to the reduction effect of ozone layer in the stratosphere and appearance of the "acid rain".

On the other hand, many composite rocket propellants incorporate aluminium fine particles. Aluminium has two different roles in the composite propellants: as a combustion stabilizer or as an impulse amplifier of the propellant. In that case, a number of liquid molten aluminium agglomerates are formed on the burning surface against the gaseous products, showing a visible smoke.

It would be necessary to use other ingredients, more favourable for the environment, while maintaining the existing advantageous characteristics.

In this paper the possibility exchange of aluminium and magnesium will be considered, based on behaviour consequences.

\section{Theoretical part}

The based propellant characteristics, with regard to performances, are specific impulse, density, availability, safe use, ease of handling and manufacturing, etc. Ingredients with high heat of formation, high oxygen balance and high density must be selected for realizing the best propellant properties. It is possible to formulate and develop new rocket compositions, with desired performances (internal balistic, flame temperature, and mechanical properties as well as any specialized property, such as smokelessness).

The composite rocket propellant (CRP) contains a crystalline oxidizer to provide oxygen for combustion and often contains a metal to increase the heat of combustion. These materials are slurried into a liquid polymer, cast, and cured chemically at the elevated temperature.

\section{Combustion of ammonium-perchlorate products}

Ammonium perchlorate (AP) is one of the most important oxygen carriers for the CRP, and these type of propellants demonstrate superior ballistic properties, (burning rate, pressure exponent and temperature sensitivity), comparing with the others. Unlike alkaline metal perchlorates, AP has the advantage of being completely convertible to gaseous reaction products. Propellants composed of crystalline AP particles and polymeric hydrocarbons thus produce only gaseous combustion products and no condensed particles.

During the combustion, in the rocket motor, there are $\mathrm{HCl}$, $\mathrm{CO}_{2}, \mathrm{H}_{2} \mathrm{O}$ and $\mathrm{N}_{2}$, and in addition $\mathrm{OH}, \mathrm{H}$ and $\mathrm{CH}$ radicals in a small amount. All of them are generated by the decomposition of $\mathrm{AP}$. When the $\mathrm{HCl}$ molecules diffuse into the air and collide with $\mathrm{H}_{2} \mathrm{O}$ molecules therein, an acid mist is formed, giving rise to the visible white smoke. Hydrogen chloride $(\mathrm{HCl})$, besides being corrosive, in the exhaust provides nucleation sites for moisture droplets to condense upon, thereby producing a visible contrail or secondary smoke [1]. However, white smoke is generated when all mentioned molecules expell from an exhaust nozzle into a humid atmosphere.

Typical example is CRP used in rocket motors. Based on the experimental observations, white smoke is formed when relative humidity exceeds over $40 \%$. Thus, AP composite

\footnotetext{
1) Military Technical Institute (VTI), Ratka Resanovića 1, 11132 Belgrade, SERBIA

Correspondence to: Vesna Rodić; e-mail: springvesna63@gmail.com
} 
propellants without any metal particles are termed as the "reduced-smoke" propellants. On the other hand, a white smoke trail is always seen from the exhaust of a rocket motor assisted by an aluminized AP composite propellant, under any atmospheric conditions. Thus, aluminized AP composite propellants are termed as the "smoke propellants".

Hydrogen chloride $(\mathrm{HCl})$ represents the core surrounded by molecules of water vapor forming sheaves of fog droplets large enough to be visible. When the light passes through the smoke, its intensity becomes lower due to absorption and scattering of the light, which is influenced by the wavelength, size, shape and number of the particles per unit of volume. During the burning of rocket propellants, large quantities of $\mathrm{HCl}$ molecules are released into the atmosphere [2].

An amount of 503 tonnes propellant liberates about 100 tonnes of $\mathrm{HCl}$ and other chlorine containing compounds [2]. During CRP burning, the atmosphere has been polluted and hence could cause "ozone depletion" in the stratosphere. The emission of $\mathrm{HCl}$ could cause the "acid rain" and it has become a matter of serious concern all over the world.

Since AP is a valuable oxidizer due to its high oxidizer performance, safe handling, and cost effectiveness compared with other crystalline oxidizers, it is difficult to replace it with any other that might circumvent its disadvantage of the $\mathrm{HCl}$ gas generation. Various types of propellants have been proposed to eliminate the $\mathrm{HCl}$ content from the combustion products.

Several options exist for reducing the volume of $\mathrm{HCl}$ in the propellant products exhaust. They can be subdivided into various modes: neutralized, scavenged, and nonchlorine; each of them has its own unique challenges and advantages which are the functions of the chemistry and physical properties of the materials used [3].

\section{Metal fuels}

It was already said that metals are incorporated in highenergy propellants to achieve the total heat release by combustion, to increase density of the propellant, a pressure exponent $(n)$ reduction and suppression of combustion instability. Many propellants contain only nominal amounts of metal to suppress unstable combustion, while propellants for smokeless applications rigidly exclude metals. The most commonly used metal is powdered aluminium (Al), extensively used in propellant formulations for extra energy, higher heat of combustion, propellant density, combustion temperature and thus higher specific impulse $\left(I_{s p}\right)$ and also to promote stable burning.

Although powdered beryllium $(\mathrm{Be})$ has a higher theoretical energy value than aluminium, as well as high heat of combustion and low molecular weight combustion products, it is seldom used because of its extreme toxicity, and higher cost [4]. It has a poor combustion efficiency with most of the hydrocarbon binder. Boron was the star metal fuel earlier, but it has been changed because of the problems due to the formation of boron oxide on its surface. Use of zirconium or titanium has also been reported for the use in propellants which require high density - impulse. Both zirconium and hafnium have extreme electrostatic discharge sensitivities that create significant safety issues and have limited their use in energetic formulations. Magnesium $(\mathrm{Mg})$, by comparison, is relatively easy to ignite and by coating a boron particle with magnesium, the ignition characteristics of boron increase substantially. In this application, burning magnesium heats the boron particle, as well as keeping the surface relatively clear of boron oxide. So, magnesium is a preferred metal fuel. Zirconium could offer a higher performance alternative to aluminium powders in propellants but it is extremely combustible or pyrophoric in nature, and its formulations have significantly lower energy than those of $\mathrm{Al}$ or Be. Zirconium could provide up to a $20 \%$ higher density - impulse than other metals such as aluminium which is most commonly used in composite propellants [4].

\section{Propellants including aluminium}

CSP based on AP contains Al particles as a fuel component to increase their specific impulse. These particles react with oxidizer components according to:

$$
\begin{gathered}
4 \mathrm{Al}+3 \mathrm{O}_{2}=2 \mathrm{Al}_{2} \mathrm{O}_{3} \\
2 \mathrm{Al}+3 \mathrm{H}_{2} \mathrm{O}=\mathrm{Al}_{2} \mathrm{O}_{3}+3 \mathrm{H}_{2}
\end{gathered}
$$

forming aluminium oxide $\left(\mathrm{Al}_{2} \mathrm{O}_{3}\right)$. This oxidation process occurs at the surface of each $\mathrm{Al}$ particle in the liquid and/or solid phase. A large number of the aluminium particles agglomerates to form large $\mathrm{Al}_{2} \mathrm{O}_{3}$ particles, with diameters of the order of $0.1 \mathrm{~mm}$ to $1 \mathrm{~mm}$. When these particles are dispersed from a nozzle into the atmosphere, a dense white smoke is formed as a trail of the rocket projectile trajectory. In general, the mass fraction of aluminium particles contained within high-energy AP composite propellants ranges from 0.10 to 0.18 , and the majority of their white smoke is caused by the dispersal of aluminium oxide particles in the atmosphere [4].

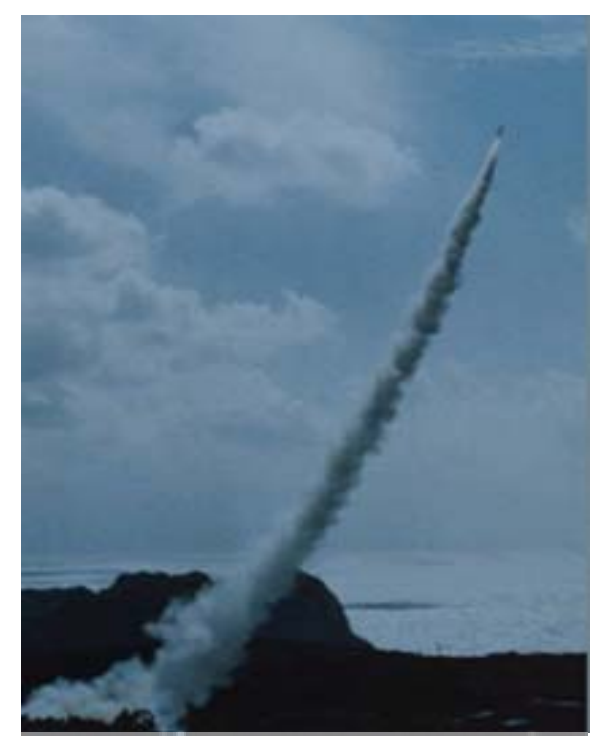

Figure 1. A typical smoke trail of a rocket projectile fuelled by an CRP/AP/Al

CRP/AP propellants without aluminium are termed "reduced smoke propellants" and are employed in tactical missiles to conceal their launch site and flight trajectory. It was already said that no visible smoke is formed when the relative humidity of the atmosphere is less than about $40 \%$ and air temperature above $0^{\circ} \mathrm{C}$. The presence of metallic particles and/or their oxide particles generate thin smoke trails. The white smoke trail includes the white fog generated by the $\mathrm{HCl}$ molecules and the condensed water vapor of the humid atmosphere [4].

Though increasing the ratio of metal component to AP up to the stoichometric point increases the combustion temperature, the presence of decreasing molar fraction of metal oxide $\left(\mathrm{Al}_{2} \mathrm{O}_{3}\right)$, precipitating from the gaseous solution creates globules of solids or liquids that slow down the flow velocity as the mean molecular mass of the flow increases. The chemical composition of the gases change, varying the 
effective heat capacity of the gas. Because of that, there exists an optimal non-stechiometric composition for maximizing $I_{s p}$ of roughly 16 mas. $\%$, assuming that the combustion reaction goes to completion inside the combustion chamber.

The combustion time of the Al particles in the hot gas varies depending on the particle size and shape. In small experimental motors with high $\mathrm{Al}$ content, the residence time of the combustion gases does not allow for full combustion of the $\mathrm{Al}$ and thus a substantial fraction of the $\mathrm{Al}$ is burned outside the chamber, leading to decreased performance. This effect is often mitigated by reducing the Al particle size, inducing turbulence, and/or by reducing the $\mathrm{Al}$ content to ensure a combustion environment with a higher net oxidizing potential, ensuring more complete $\mathrm{Al}$ combustion (even $\mathrm{Al}$ droplets are still liquid at $3000 \mathrm{~K}$ ).

\section{Reduction of $\mathrm{HCl}$ by the formation of metal chlorides}

High-temperature $\mathrm{HCl}$ molecules tend to react with metal particles. When particles of $\mathrm{Mg}$ compounds are incorporated into AP composite propellants, magnesium chloride is formed. Chemicals containing $\mathrm{Mg}$ atoms react with $\mathrm{HCl}$ after their thermal decomposition in the combustion chamber by the following reactions [5]:

$$
2 \mathrm{Mg}+\mathrm{O}_{2}=2 \mathrm{MgO}
$$

in the presence of humidity:

$$
\mathrm{MgO}+\mathrm{H}_{2} \mathrm{O}=\mathrm{Mg}(\mathrm{OH})_{2}
$$

hydroxide formed as very alkali compound, reacts with hydrogen chloride:

$$
\mathrm{Mg}(\mathrm{OH})_{2}+2 \mathrm{HCl}=\mathrm{MgCl}_{2}+\mathrm{H}_{2} \mathrm{O}
$$

The running of those reaction is proved in the laboratory and in small scalled motors either. According to the laboratory data, $\mathrm{HCl}$ could be completely removed from the product gases by the neutralized reaction if the aerosol $\mathrm{MgO} / \mathrm{H}_{2} \mathrm{O} / \mathrm{HCl}$ is formed. On the other hand, in case of a very high dispersion speed of the cloud products after the combustion period in the rocket motor, the neutralization could not be finished on time $[4,5]$.

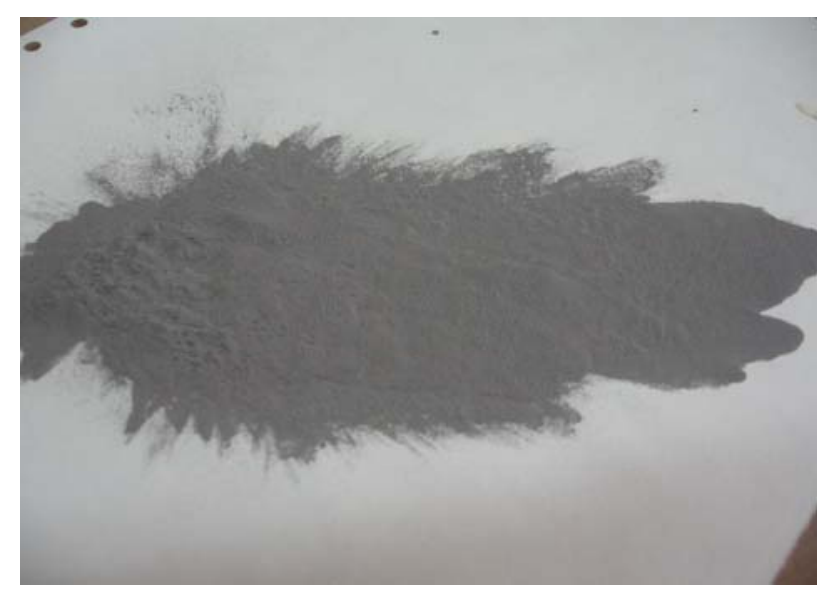

Figure 2. Magnesium powder

Thus, the number of $\mathrm{HCl}$ molecules is reduced when magnesium particles are incorporated into AP propellant. This class of propellants is termed the "neutralized propellants". The $\mathrm{HCl}$ gas among the combustion products of the AP propellant is converted into magnesium chloride, which is a stable and environmentally benign material. Since $\mathrm{Mg}$ particles act as a fuel component, similarly to the Al particles, the specific impulse of neutralized propellants increases with increasing $\mathrm{Mg}[4,5,6]$.
Table 1: Physicochemical properties of solid particles used as fuel components and AP

\begin{tabular}{||c|c|c|c|c||}
\hline \hline Solid particles & $\begin{array}{c}\text { Density, } \\
\left(\mathrm{kg} \mathrm{m}^{-3}\right)\end{array}$ & $T_{\mathrm{mp}}(\mathrm{K})$ & $\begin{array}{c}\mathrm{H}_{c} \\
\left(\mathrm{MJ} \mathrm{kg}^{-1}\right)\end{array}$ & $\begin{array}{c}\text { Oxidized } \\
\text { products }\end{array}$ \\
\hline \hline Aluminium & 2700 & 934 & 16.44 & $\mathrm{Al}_{2} \mathrm{O}_{3}$ \\
\hline Magnesium & 1740 & 922 & 14.92 & $\mathrm{MgO}$ \\
\hline Titanium & 4540 & 1998 & 8.50 & $\begin{array}{c}\mathrm{TiO}, \mathrm{Ti}_{2} \mathrm{O}_{3}, \mid \\
\mathrm{TiO}_{2}\end{array}$ \\
\hline Zirconium & 6490 & 2125 & 8.91 & $\mathrm{ZrO}_{2}$ \\
\hline Boron & 2340 & 2573 & 18.27 & $\mathrm{~B}_{2} \mathrm{O}_{3}$ \\
\hline
\end{tabular}

$T_{m p}$ : melting point temperature; $H_{c}$ : heat of combustion

Specific impulse values of neutralized propellants are very close to conventional aluminized, however with lower corresponding density values for $\mathrm{Al}$ and $\mathrm{Mg}$, according to Table 1 [7].

\section{Experimental part}

Compositions have been based on:

- constant bimodal ratio of ammonium perchlorate powder $(65 / 35)$, average particle sizes of $200 \mu \mathrm{m}$ and $7 \mu \mathrm{m}$,

- constant total solid phase (80 mas.\%) and

- constant binder composition.

There is a referent (blank) formulation (No 17, Table 2). Two compositions, No 20 and 23, were made with Al powder, (constant bimodal ratio 1:1, average particle size of fraction $15 \mu \mathrm{m} / 30 \mu \mathrm{m}$,) and four batches including Mg powder, No 60, 61, 62 and 63, (purity 99,95\%, $44 \mu \mathrm{m}$ - 325 Mesh), also shown in Table 2.

Table 2. Prepared propellant compositions

\begin{tabular}{|c|c|c|c||}
\hline No & AP-200 [mas.\%] & AP-7 [mas.\%] & $\begin{array}{c}\text { Al*/Mg** } \\
{[\mathrm{mas} . \%]}\end{array}$ \\
\hline \hline 17 & 52 & 28 & - \\
\hline 20 & 48.75 & 26.25 & $5^{*}$ \\
\hline 23 & 45.50 & 24.5 & $10^{*}$ \\
\hline 60 & 48.75 & 26.25 & $5^{* *}$ \\
\hline 61 & 45.50 & 24.50 & $10^{* *}$ \\
\hline 62 & 42.25 & 22.75 & $15^{* *}$ \\
\hline 63 & 39.00 & 21.00 & $20^{* *}$ \\
\hline
\end{tabular}

The binder of the propellant has been based on hydroxyl terminated polybutadiene (HTPB), commercially named R$45 \mathrm{M}$ (Arco), as prepolymer and isophorone-diisocyanate, (IPDI) as a curing agent; dioctyl adipate (DOA) was added as a plasticizer, triethylene tetramine (TET) as a bonding agent and 2,2'-methylenebis(6-tert-butyl-4-methylphenol), (AO22) as an antioxidant.

An undiserable higroscopy of AP should be prevented by drying process, Fig.3.

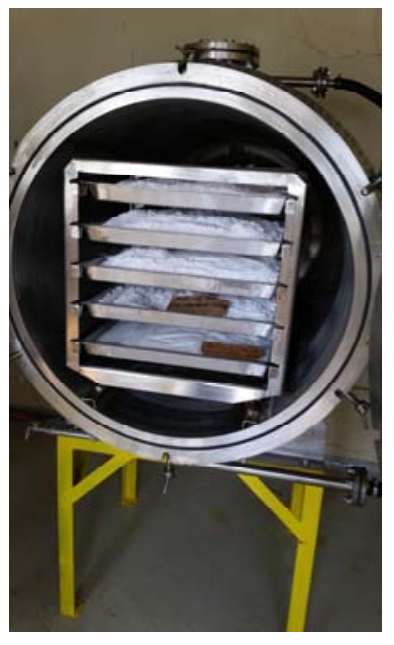

Figure 3. Dryer of oxidans powder 
The control of powder's particle size is very important, especially of the AP particle size distribution and its influence on burning rate law. Average particle diameter value was 7,1 $\mu \mathrm{m}$, measured at the Fischer Subsieve sizer.

Ingredients have been homogenized in the laboratory vertical planetary mixer, in vacuum, at $60^{\circ} \mathrm{C}$, according to mixing sheet with certain programme of adding all components (premix, consecutive adding of dried bimodal AP and curing agent at the end of the process), Fig.4.

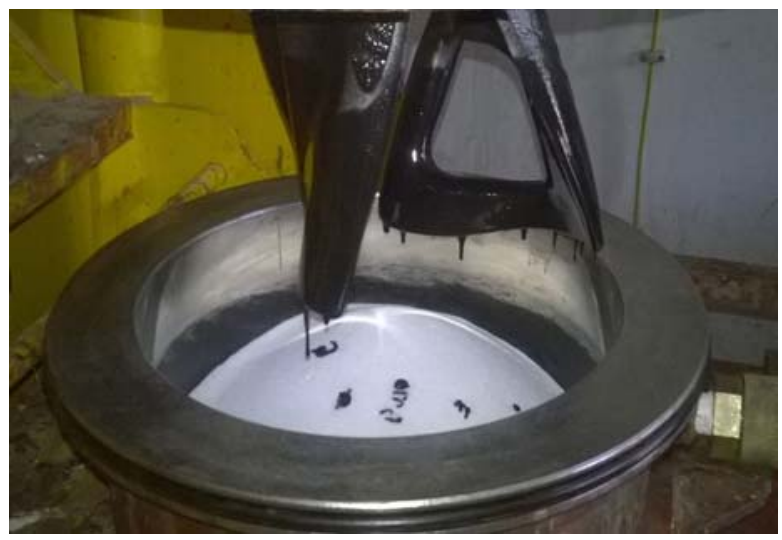

Figure 4. Blades of mixer after oxidans dosing

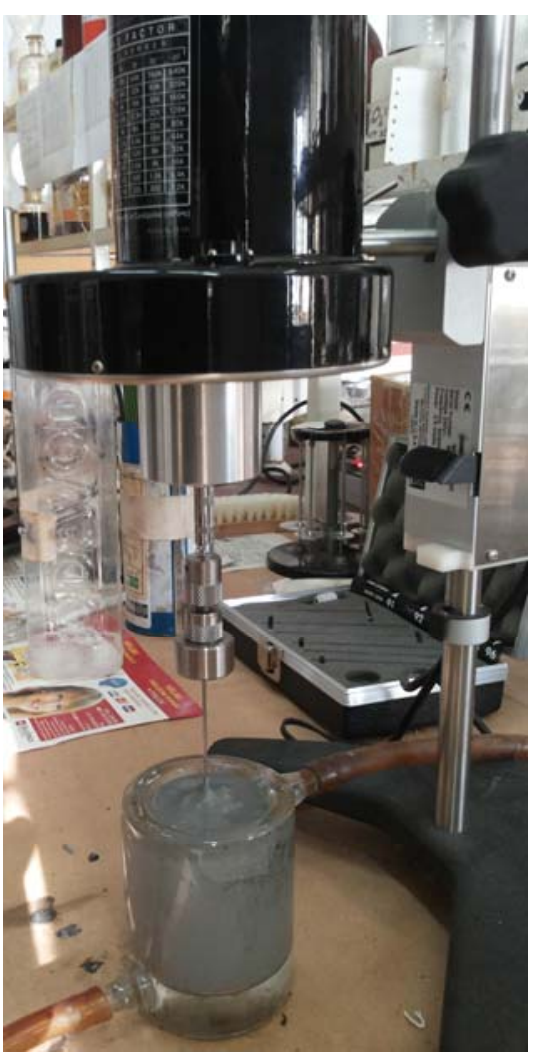

Figure 5. Griphin's glass

After finishing the mixing process, in the very beginning of the cure time, a small amount of uncured propellant had been taken from the bowl and transferred into the Griphin's glass, shown in Fig.5, as a part of the device for measuring the apparent viscosity values every 15 minutes. These values have been read out from Brookfield HBT viscosymeter dial, at $(60 \pm 2)^{\circ} \mathrm{C}$.

The casting of other specimens takes place directly from the bowl:

(i) into the chambers of 2 inch experimental motors, shown in Fig.6, that are used in the static examinations at the test station for solid rocket propellants and

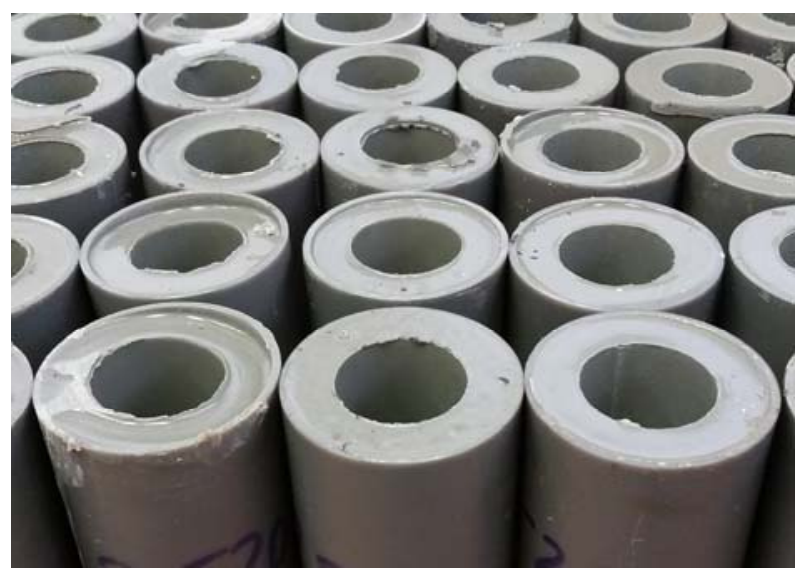

Figure 6. Cast grains for 2 inch motors

(ii) onto a cardboard mould which is shaped like a block where the propellant has been cured; later, the specimens for mechanical and energetic characteristics have been cut from the block.

Energetic values, such as heat of combustion, where determined at isoperibolic calorimeter C2000, measurements of density at Mohr balance in isopropyl alcohol as referent fluid at $20^{\circ} \mathrm{C}$, and uniaxial mechanical tensile characteristics at universal tester, Fig. 7.

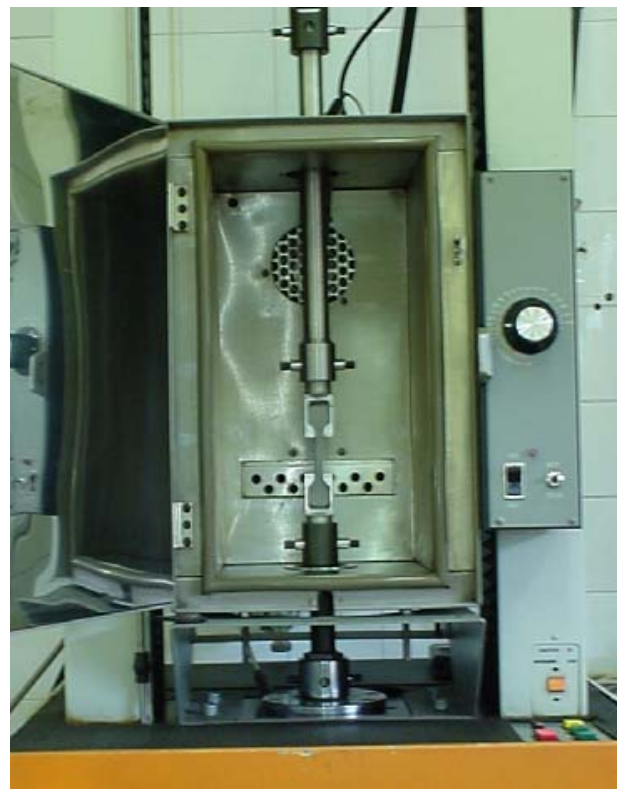

Figure 7. Universal tester for tensile measurements

Small propellant grains for the static tests (Fig.6) and block were cured at $(70 \pm 2)^{\circ} \mathrm{C}$ for 120 hours at temperature chamber, shown in Fig.8.

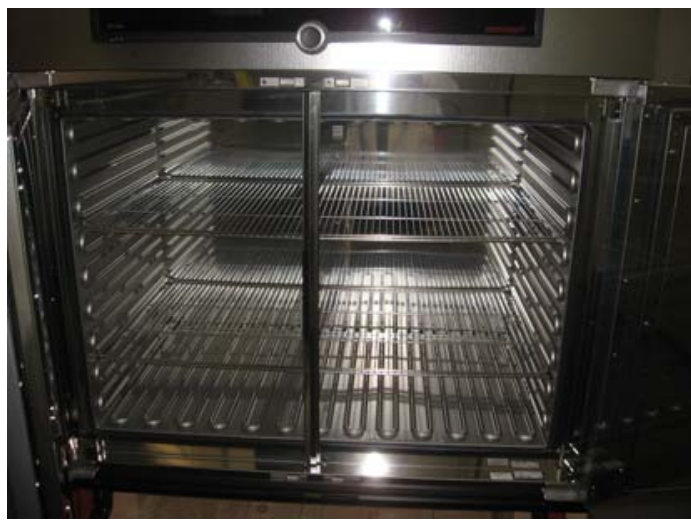

Figure 8. Temperature chamber for curing propellants 
After that, the grains in two inch chambers have been laborated into the test motors with appropriated nozzles and igniter, shown in Fig.9.

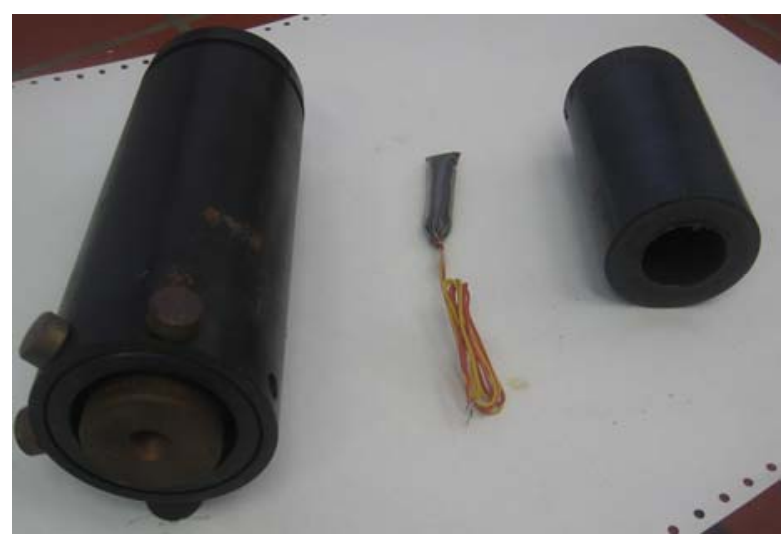

Figure 9. Two inch motor: grain, igniter and metal parts

Propellant from the block has been cut into the slabs for the examinations. After that, the specimens are ready for tempering up to the test conditions in the temperature chamber. Then they are used for various measuring, like uniaxial mechanical testing. The rest of the slabs are used for density and heat of combustion determining.

\section{Results of examinations}

All calculated values from the previously mentioned examinations are shown in the following tables.

The changing of uncured propellants viscosity values during the prolonged period of curing time at $60^{\circ} \mathrm{C}$ are given in Table 3 .

Table 3. The change of viscosity values of the propellants

\begin{tabular}{|c|c|c|c|c|c|c||}
\hline \multirow{2}{*}{ No } & \multicolumn{7}{|c||}{ Viscosity (Pa·s) vs. time (min) } \\
\cline { 2 - 7 } & 15 & 30 & 45 & 60 & 75 & 90 \\
\hline \hline 17 & 97.6 & 102.4 & 129.6 & 147.2 & 184 & 216 \\
\hline 20 & 73.6 & 86.4 & 110.4 & 128 & 150.4 & \\
\hline 23 & 72 & 86.4 & 105.6 & 121.6 & 148.8 & \\
\hline 60 & 88 & 81.6 & 81.6 & 86.4 & & \\
\hline 61 & 87.7 & 99.8 & 105.6 & 108.8 & 112 & 118.4 \\
\hline 62 & 158.7 & 178.6 & 181.8 & 192.6 & 201.6 & \\
\hline 63 & 272 & 305.6 & 323.2 & 337.6 & 353.6 & 368 \\
\hline
\end{tabular}

The uniaxial mechanical characteristics were determined by tensile tests at standard environment temperature and the results are shown in Table 4, where:

$\sigma_{m}$ - tensile strength and

$\varepsilon_{m}$ - strain at maximum stress.

Table 4. The values of mechanical characteristics at $20^{\circ} \mathrm{C}$

\begin{tabular}{|c|c|c|}
\hline No & $\sigma_{m}\left[\mathrm{daN} \cdot \mathrm{cm}^{-2}\right]$ & $\varepsilon_{m}[\%]$ \\
\hline \hline 17 & 7.90 & 32.90 \\
\hline 20 & 8.08 & 29.76 \\
\hline 23 & 7.82 & 32.51 \\
\hline 60 & 10.99 & 12.27 \\
\hline 61 & 10.20 & 23.74 \\
\hline 62 & 8.91 & 32.42 \\
\hline 63 & 13.00 & 12.65 \\
\hline
\end{tabular}

The burning rate law parameters were examined from burning tests diagrams $p=f(t)$, obtained by performing the static tests at $20^{\circ} \mathrm{C}$ and the results are presented in Table 5: burning rate values at 70 bar $\left(v_{70}\right)$, pressure exponents $(n)$ and constant (B) [8].
Table 5. Burning rate law parameters at $20^{\circ} \mathrm{C}$

\begin{tabular}{||c|c|c|c||}
\hline No & $v_{70}\left(\mathrm{~mm} \cdot \mathrm{s}^{-1}\right)$ & $n$ & $B$ \\
\hline \hline 17 & 6.62 & 0.2138 & 2.6676 \\
\hline 20 & 6.98 & 0.3068 & 1.8961 \\
\hline 23 & 6.58 & 0.3550 & 1.4567 \\
\hline 60 & 6.86 & 0.3258 & 1.7179 \\
\hline 61 & 6.80 & 0.3535 & 1.5149 \\
\hline 62 & 7.41 & 0.4294 & 1.1955 \\
\hline 63 & 7.43 & 0.4411 & 1.1412 \\
\hline
\end{tabular}

The test results of density $(\rho)$ and heat of combustion $(Q)$ determinations are represented in Table 6.

Table 6. Density and heat of combustion values

\begin{tabular}{|c|c|c||}
\hline No & $\rho\left[\mathrm{kg} \cdot \mathrm{m}^{-3}\right]$ & $Q\left[\mathrm{~kJ} \cdot \mathrm{kg}^{-1}\right]$ \\
\hline \hline 17 & 1594 & 4294.1 \\
\hline 20 & 1612 & 4652.9 \\
\hline 23 & 1632 & 4941.7 \\
\hline 60 & 1593 & 4704.6 \\
\hline 61 & 1580 & 4894.4 \\
\hline 62 & 1598 & 5342.3 \\
\hline 63 & 1575 & 5133.8 \\
\hline
\end{tabular}

\section{Discussion}

Aluminium has two roles in composite propellants: at first, in a small amount (up to about 5 mas.\%), the combustion stability of system is improved, and second, by adding a large portions, the specific impulse of the propellant is increased, but the stability level becomes very undesirable. The possibilities of decreasing a smoke of the propellant and maintaining the combustion stability at some expected level have been the main reasons for our considerations by exchanging $\mathrm{Al}$ and $\mathrm{Mg}$. The differences among propellants including these two metal components will be represented graphically as a more convenient way of consideration and comparison, through the change of viscosity values at $60^{\circ} \mathrm{C}$, uniaxial tensile properties, energetic and density values and burning rate laws at ambient temperature.

The "pot life" (defined as the period of casting possibility) of propellants is characteristic of preparation process, represented in Fig.10 (for the referent one and Al included formulations) and Fig.11 (for the referent and formulations with $\mathrm{Mg}$ ), based on Table 3 .

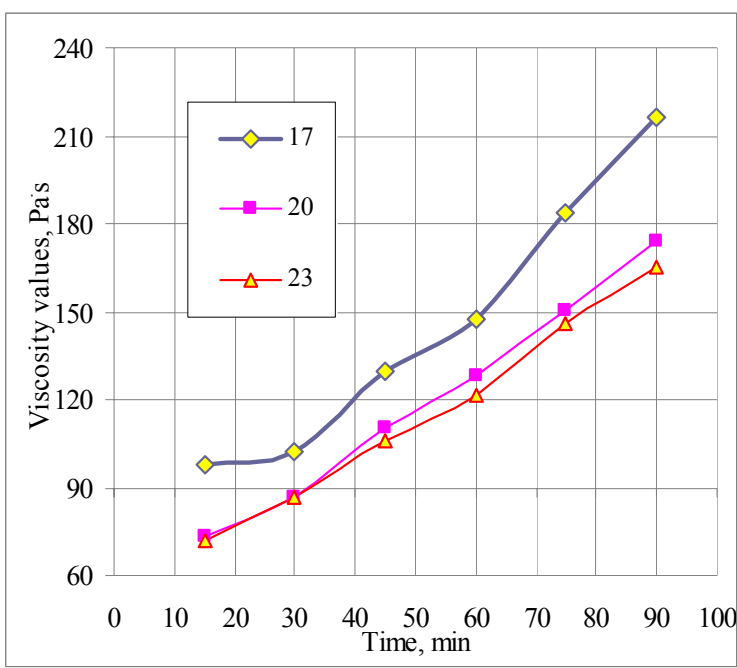

Figure 10. Viscosity changes for composition with Al

According to densities of metals, $\rho(\mathrm{Mg})=1740 \mathrm{~kg} \cdot \mathrm{m}^{-3}$ and $\rho(\mathrm{Al})=2690 \mathrm{~kg} \cdot \mathrm{m}^{-3}$, there is a significant positive influence of both (for the 5 mas. $\%$ and 10 mas.\%), because all the 
values are below the limit dependence of referent composition in the whole measuring range. This is the consequence of densities and size of metal atoms corresponding to ammonium-perchlorate, $\mathrm{NH}_{4} \mathrm{ClO}_{4}$. The huge molecule of AP $\left(\mathrm{M}=117.5 \mathrm{~kg} \cdot \mathrm{kmol}^{-1}\right)$ is exchanged with a small $\mathrm{Al},(\mathrm{M}=26.98$ $\left.\mathrm{kg} \cdot \mathrm{kmol}^{-1}\right)$, or $\mathrm{Mg}$ molecule either, $\left(\mathrm{M}=24.30 \mathrm{~kg} \cdot \mathrm{kmol}^{-1}\right)$. But in the following steps the slopes of compositions with $\mathrm{Mg}$ are lower and it could be said that the use of $\mathrm{Mg}$ is more convenient for increasing of pot life than $\mathrm{Al}$, even up to 15 mas.\%. The reason why it happens is the density of these three solids in the sequence $\mathrm{Mg}, \mathrm{AP}, \mathrm{Al}$, and the molar masses of each of them. It is very important fact that the exchange of $\mathrm{AP} / \mathrm{Mg}$ in the higher content of metal parts leads to a very slight slopes of viscosity changing in comparison to the referent for AP/Al propellant. Finally, after 90 minutes the composition with 15 mas.\% of $\mathrm{Mg}$ shows almost the same viscosity level as the referent propellant. The packaging of different types and sizes of molecules could not be neglected [9]. The dependence of viscosity vs. time is the fact important as the production and quality parameter.

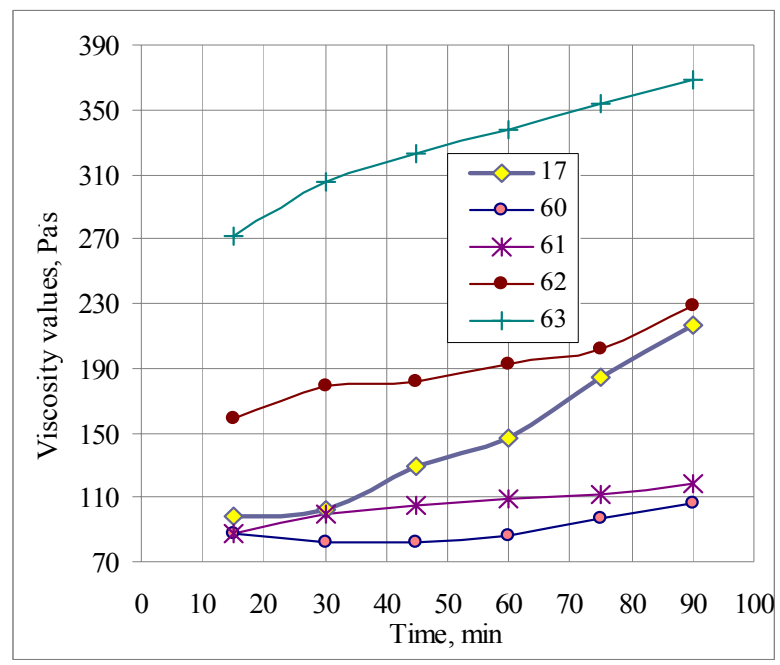

Figure 11. Viscosity changes for composition with $\mathrm{Mg}$

The effects of both, $\mathrm{Al}$ and $\mathrm{Mg}$ on tensile strength and strain at maximum stress were presented in Figures 12 and 13, respectively.

The same AP coarse/fine particles ratio was used in all prepared formulations. Adding of metals has never changed $65 / 35$ ratio between $200 \mu \mathrm{m}$ and $7 \mu \mathrm{m}$ particles of AP. So the effect of the contact surface could be eliminated in this way.

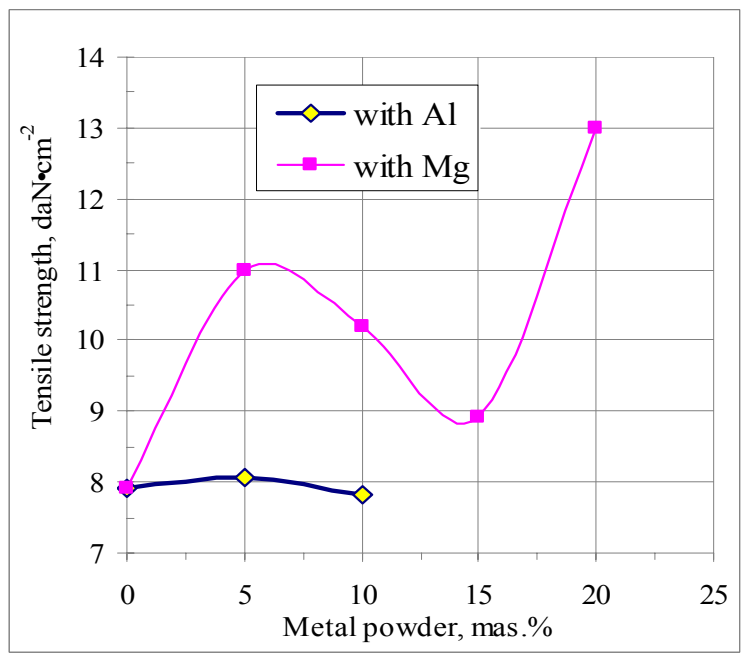

Figure 12. Tensile strength values of propellants with $\mathrm{Al}$ and $\mathrm{Mg}$
General view of the mechanical characteristics shows higher tensile strength and lower strains of the propellants with $\mathrm{Mg}$ than those including $\mathrm{Al}$. The referent formulation (point at the ordinate axis), contains only polar molecules of AP that have been influenced by bonding agent [10]. The participation of metal powder has a significant effect on increasing the strength of any material, so these propellants are brittler hopely due to the resistance to external load [11]. On the contrary, the presence of metal particles contributes to decreasing of AP covered bonding agents ratio and hence, the drop of strains. The $\mathrm{Al}$ powder is a mixture of $15 \mu \mathrm{m}$ and 30 $\mu \mathrm{m}$ fractions, and $\mathrm{Mg}$ contains particles up to $44 \mu \mathrm{m}$. It is supposed that the increase of tensile strength (and decrease of strain) in case of $\mathrm{Mg}$ are the consequence of the formed complex compound.

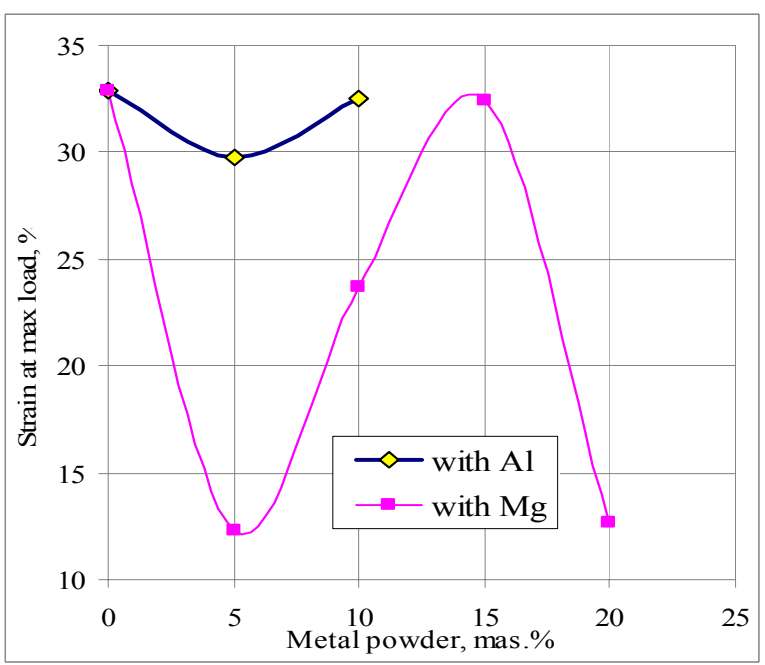

Figure 13. Strain at maximum load of propellants with $\mathrm{Al}$ and $\mathrm{Mg}$

The values of strain at maximum load (Fig.13) correspond to those that have just been discussed.

Accordingly with the densities of the used components $\mathrm{Mg}$, $\mathrm{AP}, \mathrm{Al}$, that increase in the following rank:

$$
1740>1950>2690 \mathrm{~kg} \cdot \mathrm{m}^{-3},
$$

so it is expected that the exchange of perchlorate molecules with aluminium (higher density) leads to an increase in value, in opposite to the exchange of perchlorate molecules with magnesium, as can be seen in Fig.14. The mode od packing in the course of exchanging AP and metals, due to dimensionality of these three molecules, dictates the level of propellant densities.

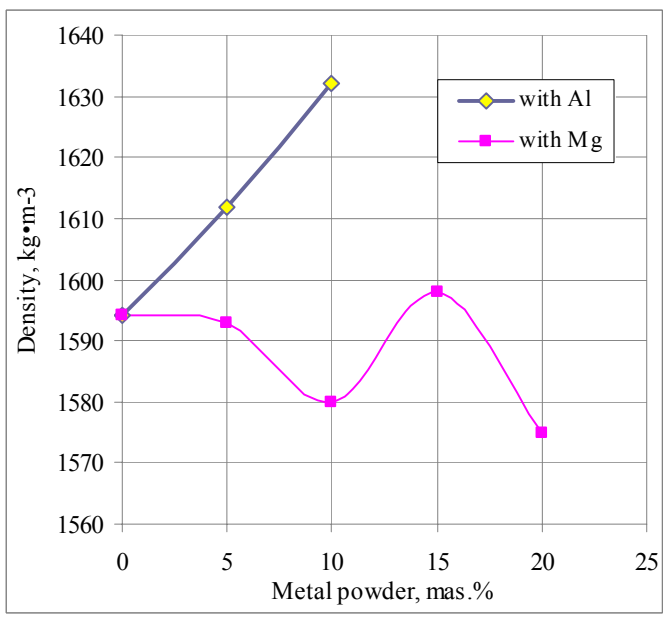

Figure 14. Density values of propellants with $\mathrm{Al}$ and $\mathrm{Mg}$ 
It is very important to say that fluctuations of density measuring (Fig.14) are most likely a consequence of scattering of $\mathrm{Mg}$ particles from the propellant sample owing to the weak bonds between the binder and the Mg particles, with a reminder of larger sizes of $\mathrm{Mg}$ than bimodal, but even smaller particles of Al. It is always a problem in cases of heterogeneity of samples like CRP is: reproducibility of the test results, same as the heat of combustion examinations.

The energies of propellants released as heat during the combustion process are given in Fig. 15.

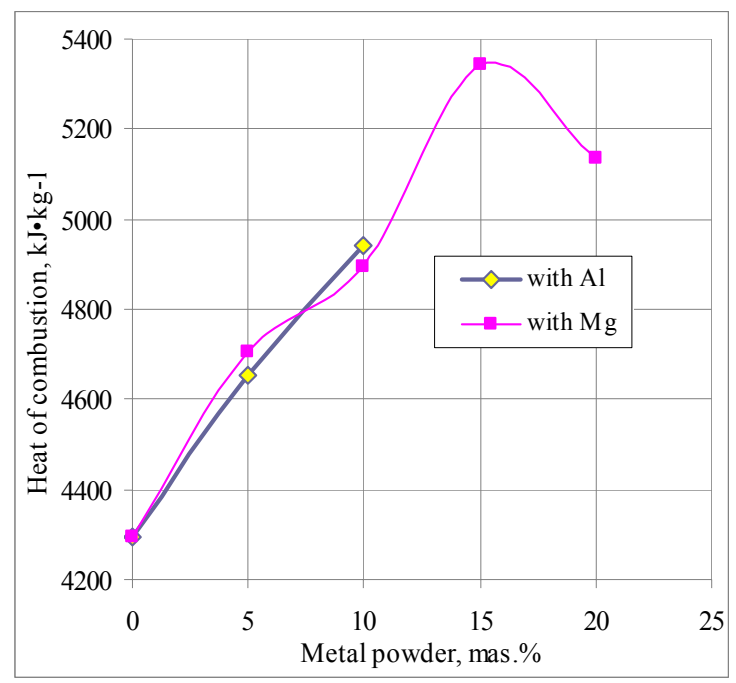

Figure 15. Heat of combustion of $\mathrm{Al} / \mathrm{Mg}$ propellants

Adding the metal powder into the composite propellants increases the heat of combustion value corresponding to the propellants based on AP, that shows exotermic decomposition before melting at $200^{\circ} \mathrm{C}$, but it is important to notice that the autoignition temperature of the oxidizer is $240^{\circ} \mathrm{C}$.

The parameters of burning rate law are presented in few following diagrams. The first one, in Fig.16, shows the Al propellants in comparison to the referent propellant including 80 mas.\% of oxidizer, (see Table 2 ), without any metal fraction.

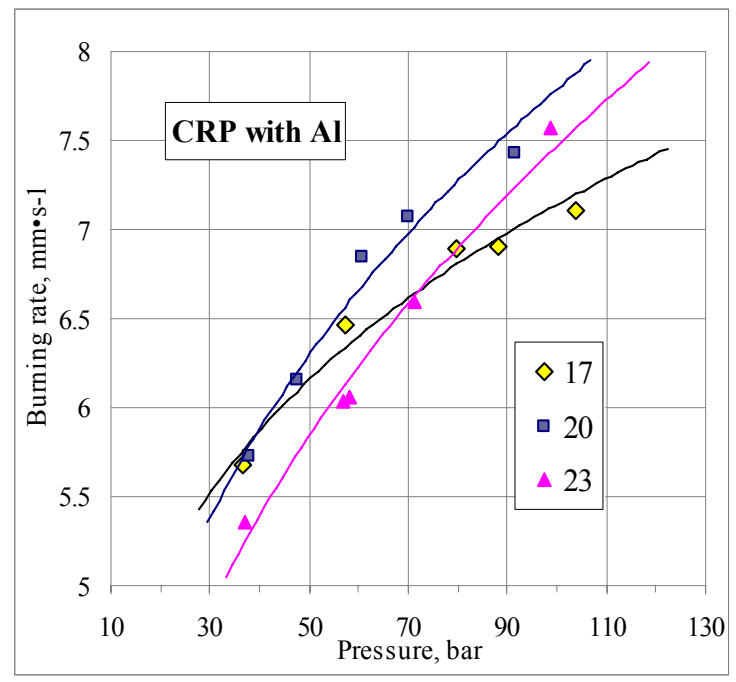

Figure 16. Burning rate law of propellants with $\mathrm{Al}$

It is obvious that adding $\mathrm{Al}$ increases the exponents of pressure, i.e. the dependencies of burning rate/pressure are steeper than those for the propellants without Al. In these systems, the larger presence of Al leads to a decrease of the burning rate, but nominally related values could depend on the operating pressure [8]. For example, from the Fig.16 it is obvious that CRP with 10 mas.\% Al (No23) up to 70 bar gives the burning rates lower than nonaluminized propellant (No17). The same appearance has come at about 40 bar for CRP with 5 mas. $\%$.

The linear burning rate of solid propellant is the velocity of chemical reaction progress as a result of thermal conduction and radiation (perpendicular to the current surface of the propellant). It depends on:

- chemical composition,

- pressure, temperature and

- physical state of the propellant (porosity, particle size distribution of the components, compression).

The formed gas cloud flows in the direction opposite to the burning course. The burning rate describes the velocity with which the volume of the burning propellant changes [12]. In some cases, the anomalous increase in the burning rate is recognized. This increase is originated from a turbulent instead of a laminar gas flow along the burning surface, which leads to a higher feed back of heat energy onto this surface, and thus a higher rate of burning. Mechanical erosion may also take place by gases rich in solid particles, e.g. $\mathrm{Al}_{2} \mathrm{O}_{3}[13]$.

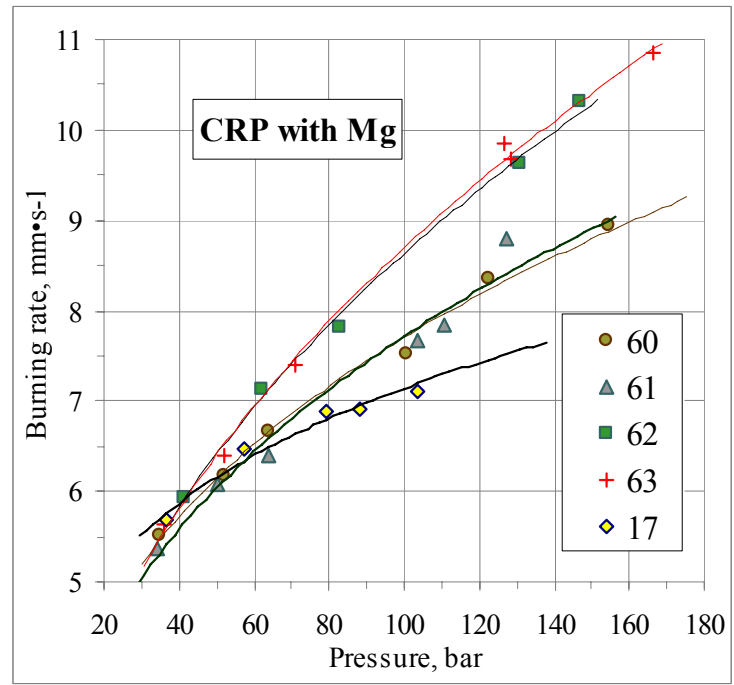

Figure 17. Burning rate law of propellants with $\mathrm{Mg}$

In the propellants with $\mathrm{Mg}$, Fig.17, the larger content leads to higher burning rates at almost the whole operating pressure region above 40 bar, but somewhat different than the $\mathrm{Al}$ propellants: for those including 5 mas. $\%$ and 10 mas. $\% \mathrm{Mg}$, the section point of considered and referent propellants is almost the same, at 50 -55 bar, and for 15 mas.\% and 20 mas.\%, the mutually intersection point is about 40 bar. Unlike the $\mathrm{Al}$ propellant samples, by increasing the $\mathrm{Mg}$ content, the limits of increasing burning rates in comparison to the referent one are expanded.

It would be interesting to compare the burning rate laws for the same metal content systems: for 5 mas.\% (Fig. 18) and for 10 mas.\% (Fig.19), but also in relation to the burning rate law of the referent AP propellant.

It is obvious that the tendency of burning rate to increase is proportional to the content of $\mathrm{Mg}$ (or Al) in the propellants, i.e. the rise and drop for the $\mathrm{Al}$ propellants are greater than for $\mathrm{Mg}$ CRP, as it is seen in Fig.20. Conclusions about the propellants behaviour including two metal contents -5 mas. $\%$ and 10 mas. $\%$, corresponding to the amplitude value of the burning rates, have to be confirmed through some repeated examinations.

The changes of exponents of pressure are shown in Fig. 21. Similar as in the case of Al, exponents of pressure are higher, and dependencies are steeper. Only for low pressures it could be said that the values for all compositions are similar (up to 4550 bar). 


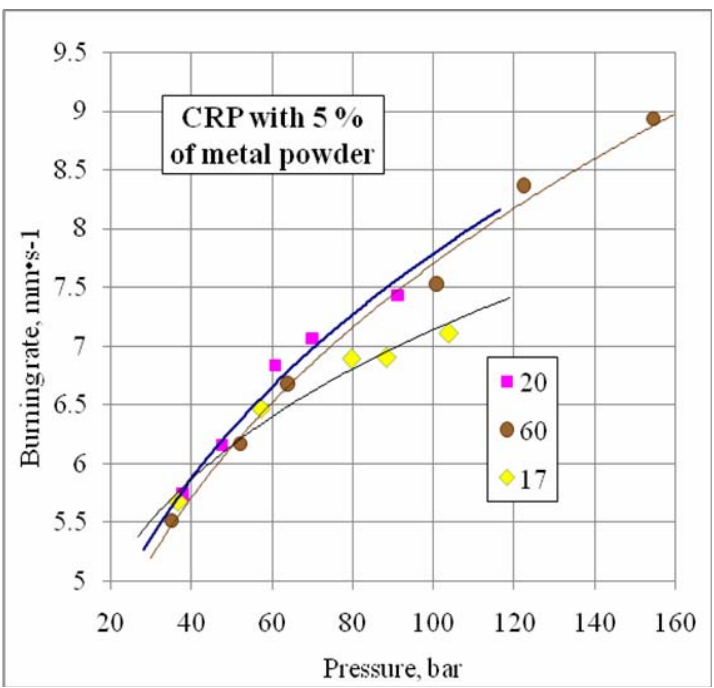

Figure 18. Burning rate law for 5 mas. $\% /$ metal powder

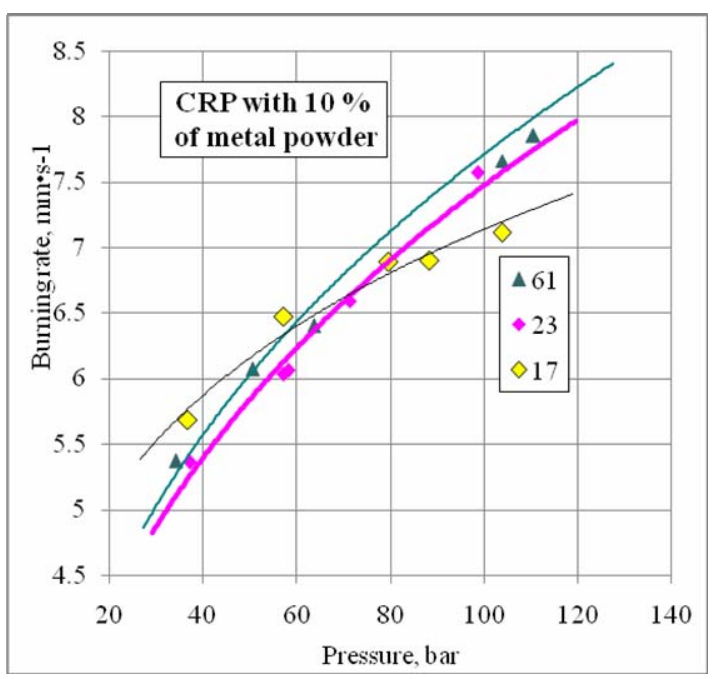

Figure 19. Burning rate law for 10 mas. $\%$ /metal powder

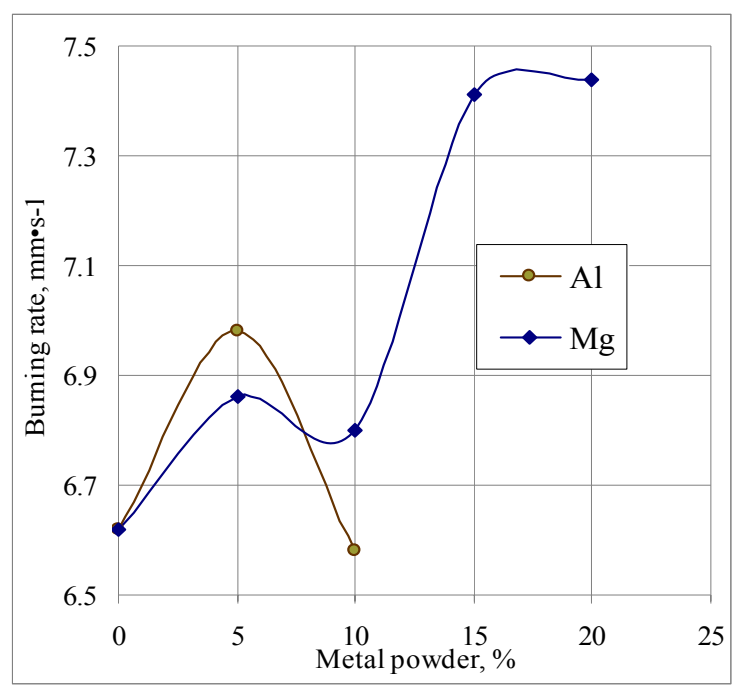

Figure 20. Burning rate vs. metal content

It should be said that the propellants with 80 mas.\% solid phase, including 15 mas. $\%$ or 20 mas. $\% \mathrm{Al}$ are not interesting as a part of impuls motors reasearch. HTPB propellant system could be filled up with solid phase even up to 90 mas.\%. Except that, aluminium oxide, formed during propellant combustion process, even at higher temperatures is melted, i.e. in liquid state that has a very undesirable effect on gas products velocity and thus, the impulse of propellant. Because of that, the formulations including more than 10 mas. $\% \mathrm{Al}$ have not been considered. Designed role of $\mathrm{Mg}$ was quite different than $\mathrm{Al}$ : to joint the chlorine products, as it was shown in the part of reduction of $\mathrm{HCl}$ by the formation of metal chlorides, in reactions (3) to (5). In practice, it would be necessary to add any components to increase the impuls and to eliminate the chlorine products [14].

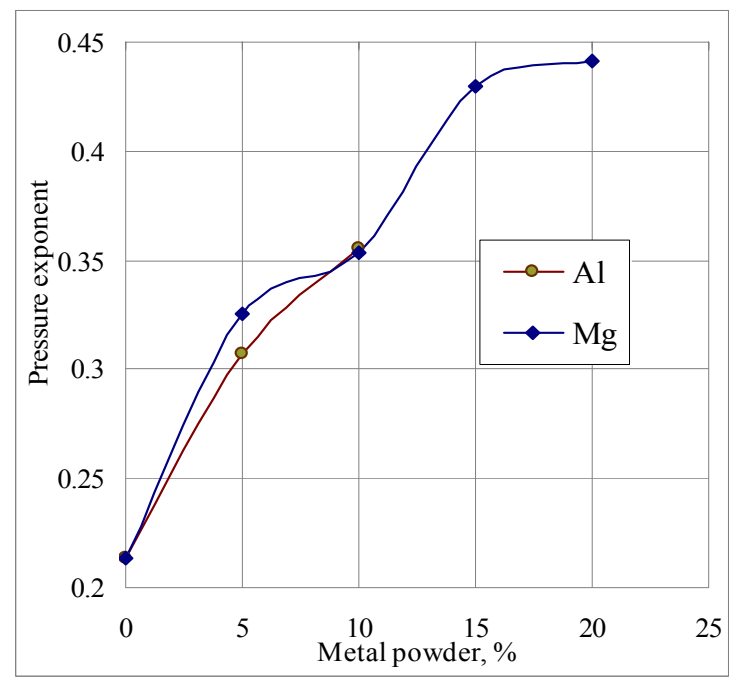

Figure 21. Pressure exponent of propellants with $\mathrm{Mg}$ and $\mathrm{Al}$

\section{Conclusion}

The possibilities of decreasing or eliminating a propellant exhausting smoke and maintaining the combustion stability at some expected level have been the main tasks of these considerations. The differences among composite solid propellants including aluminium or magnesium have been disscussed, throughout the values of viscosity, uniaxial tensile properties, energetic and density characteristics and burning rate laws.

A significant positive influence of both metals (for the 5 mas. $\%$ and 10 mas. $\%$ contents) on viscosity values has been determined, because all the measured values are below the limit dependence of referent composition in the whole measuring range, with a very slight slopes of viscosity changing. This is the consequence of densities and size of metal atoms corresponding to huge molecule of ammoniumperchlorate, which is exchanged with a smaller $\mathrm{Al}$ or $\mathrm{Mg}$ molecule. Depending on the solid phase content, share of plasticizer, powder particle sizes, the viscosity values up to 500 Pas after 90 minutes are acceptable, so this effect of $\mathrm{Mg}$ is positive.

According to the ascending order of the densities of used components $\mathrm{Mg}$, AP, Al, measured values of density are expected, and the exchange of perchlorate molecules with aluminium leads to an increase in value, in opposite in case of magnesium. The mode od packaging in the course of exchanging AP and metals, due to dimensionality of these three molecules, dictates the level of propellant densities. For the impulse motors it is very important to take place as high as possible masses in the same volume. According to this effect, the use of $\mathrm{Al}$ powder gives the higher density propellants.

Adding the metal powder into the composite propellants increases the heat of combustion value corresponding to the propellants based on AP; that is the logical consequence of the values of melting points and heats of combustion. The effects of both metal types are positive. 
Mechanical characteristics show higher tensile strength and lower strains of the propellants with $\mathrm{Mg}$ than those including Al. The participation of metal powder effects on increasing the strength of any material, so these propellants are brittler hopely due to resistance to external load. On the contrary, the presence of metal particles contributes to decreasing of AP covered bonding agents ratio and hence, the drop of strains. The effects of both are the same for the final requirements.

The larger content of $\mathrm{Mg}$ in the CRP leads to higher burning rates at almost the whole operating pressure region above 40 bar. It means that unlike Al propellant samples, by increasing the $\mathrm{Mg}$ content, the pressure areas of increasing burning rates in comparison to the referent one are expanded. Except that, by increasing the content of $\mathrm{Mg}$, the burning rate is also increased, that is different than for the $\mathrm{Al}$ propellants. That being a benefit for some propellant designing is what depends on the requirements.

Adding the metal powder increases the exponents of pressure in relation to only AP formulation: the dependencies of burning rate and pressure are steeper. The reasons for those differences may also take place by gases temperatures, solid or melted particles presence, types and molecule masses of gas products and their ability to move, etc. The propellants containing 80 mas.\% solid phase, including more than 15 mas.\% Al are not a subject of interest as a part of the impuls motors research. In HTPB propellant system it is possible to fill up the solid phase even up to 90 mas.\%. Aluminium oxide, formed during the propellant combustion process, is melted even at higher temperatures, i.e. in liquid state it has a very undesirable effect on the gas products velocity and thus the impulse of the propellant. Because of that, the formulations including more than 10 mas. $\% \mathrm{Al}$ have not been considered. On the other hand, designed role of $\mathrm{Mg}$ was completely different: to joint the chlorine products and decrease the smoke effects during combustion [5].

The most important effect is the thrust value measurement, that would be the next step in the following examinations like tests in the experimental 6 inch or some other test motor. The calculated theoretical values of a specific impuls of propellants could be deceived during the examinations and each data must be checked.

The considered formulations are only the beginning of development of the propellants with long range and at last smokeless composite solid propellants. The principal benefit of these propellants is their lack of visible signature. This enables the firing position to remain concealed and thus less vulnerable to hostile action. There is a need for development of alternate materials, for mutual purpose [14], environmentfriendly as well as more energetic for the future space requirements. Safe handling and manufacturing, environmental safety, low cost, and chemical compatibility with oxidizer and other propellant ingredients, are very important factors for newly developed propellants.

\section{Literature}

[1] KUBOTA,N.: Combustion of Composite Propellants: Combustion of Composite Propellants, in Propellants and Explosives, Thermochemical Aspects of Combustion, Wiley-VCH Verlag GmbH \& Co. KGaA, Weinheim, Germany. doi: 10.1002/9783527693481.ch7, 2015.

[2] VENKATACHALAM,S., SANTHOSH,G., NINAN,K.N.: High Energy Oxidisers for Advanced Solid Propellants and Explosives, Chapter 1 Introduction to Explosives and Propellants Advances in Solid Propellant Technology, P1 International HEMS1 Workshop, Ranchi, India, 2002, pp. 87-106.

[3] BENNETT,R.R.: Low Acid Producing Solid Propellants, Propellants and Fuels, NASA. Marshall Space Flight Center, Aerospace Environmental Technology Conference, 1995, pp.105-114.

[4] KUBOTA,N.: Propellants and Explosives, Thermochemical Aspects of Combustion, Second, Completely Revised and Extended Edition, p. 74. Weinheim, Germany 2007.

[5] MAHANTA,A.K., PATHAK,D.D.: Recent Advances in Development of Eco-friendly Solid Composite Propellants for Rocket propulsion, Res. J. Chem.Environ., Sept. 2010, Vol.14(3), pp.94-103.

[6] SHALINI,C., PRAGNESH,N.D.: Solid propellants: AP/HTPBcomposite propellants, Review Department of Chemistry, Krantiguru Shyamji Krishna Verma Kachchh University, Gujarat, India, 2014.

[7] KUBOTA,N.: Propellants and Explosives, Thermochemical Aspects of Combustion, Second, Completely Revised and Extended Edition, Weinheim, Germany, 2007, p.456.

[8] WEIDONG,C., PIYUSH,T., VIGOR,Y.A.: Model of AP/HTPB Composite Propellant Combustion in Rocket-motor Environments, Combust. Sci. and Tech., 2008, 180: 2143-2169.

[9] TOKUI,H., IWAMA,A.: Pot life Problem and its Measure with a Reduced Smoke Propellant Production, Propellants, Explosives, Pyrotechnics, 1991, 16, pp.105-109.

[10] KEIICHI,H., AKIRA,I.: Enhancement of Matrix/Filler Adhesion in $H M X / H T P B$ Composite Propellant, Propellants, Explosives, Pyrotechnics, 1985, No.10, p.176.

[11] BRZIĆ,S., JELISAVAC,LJ., GALOVIĆ,J., SIMIĆ,D., PETKOVIĆ,J.: Viscoelastic properties of Hydroxyl-terminated poly(butadiene) based composite rocket propellants, Chem. Ind., 2014, 68(4), pp.435-443.

[12] MEYER,R., KÖHLER,J., HOMBURG,A.: Explosives. Wiley-VCH, Verlag, GmbH \& Co. KG aA, Fifth Edition, 2002.

[13] BABUK,V.A.: Problems in Studying Formation of Smoke Oxide Particles in Combustion of Aluminized Solid Propellants, Combustion, Explosion, and Shock Waves, 2007, Vol.43, No.1, pp.38-45.

[14] RODIĆ,V., BOGOSAVLJEVIĆ,M., MILOJKOVIĆ,A., BRZIĆ,S., FIDANOVSKI,B., GLIGORIJEVIĆ,N.: Preliminary Research of Composite Rocket Propellants Including Octogene, Scientific Technical Review, ISSN 1820-0206, 2017, Vol.67, No.1, pp.3-12.

\title{
Mogućnost zamene aluminijuma magnezijumom u kompozitnim raketnim gorivima
}

\begin{abstract}
U radu su prikazana istraživanja kompozitnih raketnih goriva na bazi amonijum perhlorata, hidroksiterminiranog polibutadiena i izoforon diizocijanata koji sadrže jednu od dve metalne komponente, aluminijum ili magnezijum, različitih sadržaja u gorivu. Masa metalnog praha je povećavana na račun oksidatora, konstantnog bimodalnog sastava, uz konstantan udeo čvrste faze. Određivani su parametri zakona brzine sagorevanja, vrednosti prividnog viskoziteta, jednoosne mehaničke karakteristike, gustina i energetske vrednosti i međusobno poređene sa rezultatima istraživanja dimljivih sastava.
\end{abstract}




\title{
Possibilité de substitution de l'aluminium par le magnésium dans les propergols composites
}

\begin{abstract}
Dans ce travail on a présenté les recherches sur les propergols composites basés sur l'ammonium perchlorate polybutadiène hydroxy terminé et l'isophorone dyisocyanate qui contiennent une ou deux composantes en métal, aluminium ou magnésium, de différents contenus dans le propergol. La masse de poudre métallique a été augmentée par rapport à l'oxydant avec le contenu bimodal constant et avec une part de phase solide constante. On a déterminé les paramètres de la loi de vitesse de combustion, les valeurs de la viscosité apparente, les caractéristiques mécaniques uniaxe, la densité et les valeurs énergétiques et ensuite comparés conformément aux résultats des recherches sur les compositions de fumée.
\end{abstract}

Mots clés: propergol composite, ammonium perchlorate, polybutadiène hydroxy terminé, aluminium, magnésium, caractéristiques balistiques, caractéristiques mécaniques, résultats comparés.

\section{Возможность замены алюминия магнием в композитных ракетных топливах}

\begin{abstract}
В этой статье представлено исследование композитных ракетных топлив на основе перхлората аммония, гидрокситерминизированного полибутадиена и изофорондиизоцианатов, содержащих одну из двух металлических компонент, алюминия или магния, различных содержаний в топливе. Масса металлического порошка увеличивалась за счёт окислителя, постоянного бимодального состава, с постоянной долей твёрдой фазы. Определены параметры закона скорости сгорения, значения кажущейся вязкости, одноосных механических характеристик, плотности и значения энергии, и взаимно сопоставимые с результатами исследования плавильных соединений.
\end{abstract}

Ключевые слова: композитное ракетное топливо, перхлорат аммония, гидрокситерминизированный полибутадиен, алюминий, магний, баллистические характеристики, механические характеристики, сравнительные результаты. 